\title{
Akibat hukum terhadap jual beli tanah yang telah didahului perjanjian nominee dengan warga negara asing
}

\author{
Norentia Ekumning Sari ${ }^{1}$, Suhariningsih ${ }^{2}$, Abdul Madjid ${ }^{3}$.
}

${ }^{1}$ Norentia Ekumning Sari; Magister Kenotariatan Universitas Brawijaya; Jalan MT. Haryono 169 Malang; 65145; Jawa Timur; Indonesia.

${ }^{2}$ Suhariningsih; Magister Kenotariatan Universitas Brawijaya; Jalan MT. Haryono 169 Malang; 65145; Jawa Timur; Indonesia.

${ }^{3}$ Abdul Madjid; Magister Kenotariatan Universitas Brawijaya; Jalan MT. Haryono 169 Malang; 65145; Jawa Timur; Indonesia.

\begin{tabular}{l} 
A R T I C L E I N F O \\
\hline Article history: \\
Received 2021-02-14 \\
Received in revised form \\
2021-04-24 \\
Accepted 2021-08-01 \\
Kata kunci: \\
Perjanjian Nominee; Hukum \\
Agraria; Hak Atas Tanah.
\end{tabular}

Keywords:

Notary; Bankrupt; Legal Due.

DOI: https://doi.org/10.26905/ idjch.v12i2.5808.

How to cite item:

Sari, N., E., Suhariningsih, Madjib, A.. (2021). Akibat hukum terhadap perjanjian jual beli tanah yang telah didahului perjanjian nominee dengan warga negara asing. Jurnal Cakrawala Hukum, 12(2), 205-212. doi:10.26905/idjch.v12i2.5808.

Corresponding Author:

* Norentia Ekumning Sari.

E-mail address: Norentiarena@gmail.com

\section{Abstrak}

Artikel ini memiliki maksud dan tujuan dari adanya perjanjian nominee mengenai hak atas tanah di Indonesia. Ini terjadi karena banyak warga negara asing, yang selanjutnya disebut WNA bisa memiliki tanah di Indonesia, sedangkat hukum positif di Indonesia hanya memperbolehkan warga negara Indonesia yang dapat memiliki hak milik tanah di Indonesia Perjanjian nominee adalah penyelundupan hukum yang dapat mengakibatkan tanah dikembalikan kepada negara. Namun, dalam Putusan Pengadilan Negeri Denpasar Tahun 2013 Nomor 82/PDT.G/2013/ PN.DPS, salah satu putusan hakim adalah tanah harus dijual kembali dan hasil penjualan tanah dibagi antara asing (benefactor) dan warga negara Indonesia (legal owner) sebagai pembanding dalam pendekatan kasus untuk menganalisis jual beli tanah yang telah didahului dengan perjanjian nominee di Indonesia. adanya tindakan Penggugat yang merupakan WNA untuk menjual tanah dan bangunan tersebut sebelum adanya gugatan merupakan salah satu yang menjadi pertimbangan hakim dalam memutus perkara ini. Ditambah lagi, Tergugat I menjual tanah tersebut dibawah harga pasar. Maka perbuatan melawan hukum yang dilakukan oleh Tergugat I dengan Tergugat II atas jual beli hak atas objek sengketa harus dapat dipertanggungjawabkan oleh para Tergugat.

\section{Abstract}

This article has the intent and purpose of the nominee agreement regarding land rights in Indonesia. This happens because many foreign nationals, hereinafter referred to as foreigners, can own land in Indonesia, while positive law in Indonesia only allows Indonesian citizens who can own land ownership rights in Indonesia. 


\title{
Jurnal Cakrawala Hukum, Volume 12 No. 2 Agustus 2021
}

ISSN PRINT 2356-4962 ISSN ONLINE 2598-6538

\begin{abstract}
The nominee agreement is legal smuggling that can result in land being returned to the state. However, in the Decision of the Denpasar District Court in 2013 Number 82/PDT.G/2013/PN.DPS, one of the judges' decisions is that land must be resold and the proceeds from the sale of land are divided between foreigners (benefactors) and Indonesian citizens (legal owners) as comparison in a case approach to analyze the sale and purchase of land that has been preceded by a nominee agreement in Indonesia. the action of the Plaintiff who is a foreigner to sell the land and buildings prior to the lawsuit is one of the considerations for the judge in deciding this case. In addition, Defendant I sold the land below the market price. Therefore, the unlawful acts committed by Defendant I and Defendant II over the sale and purchase of rights to the object of the dispute must be accounted for by the Defendants.
\end{abstract}

\section{Latar Belakang}

Kepemilikan atau penguasaan tanah di Indonesia sangat mempengaruhi status sosial dari seseorang dalam bermasyarakat karena semakin banyak tanah atau semakin luas tanah yang dikuasai akan semakin tinggi status sosial seseorang tersebut dalam masyarakat. Undang-Undang No. 12 tahun 2006 tentang

kewarganegaraan khususnya ketentuan pasal 14 menjelasakan, pada intinya peduduk hanya dibedakan menjadi dua, yaitu Warga Negra Indonesia (WNI ) dan Orang Asing, dalam hal ini yang masih menjadi patokan untuk pembeda dari golongan penduduk di Indonesia (lailawati, 2020). Namun didalam UUPA sangat tegas melarang kepemilikan tanah untuk warga negara asing yang ada di Indonesia hal ini sesuai dengan aturan Pasal 9 ayat 1 "Hanya warga negara Indonesia dapat mempunyai hubungan yang sepenuhnya dengan bumi, air dan ruang angkasa, dalam batas-batas ketentuan pasal 1 dan 2". Pasal tersebut menjelaskan bahwa seluruh kekayaan alam di Indonnesia dalam hal ini tanah hanya dapat dimiliki oleh warga negara Indonesia saja.

Namun yang ada sekarang banyak warga negara asing, yang selanjutnya disebut WNA bisa memiliki tanah di Indonesia, sedangkat hukum positif di Indonesia hanya memperbolehkan warga negara Indonesia yang dapat memiliki hak milik tanah di Indonesia. WNA bisa memperoleh tanah atau hak milik hanya karena pewarisan tanpa wasiat atau percampuran harta karena perkawinan. Dalam perkembangan dunia usaha dan bisnis saat ini, para pelaku usaha semakin giat bersaing, banyaknya kekayaan alam yang terkandung ditanah air ini serta peluang untuk mengembangkan usaha yang begitu besar, menggugah kreatifitas para investor dan pengusaha asing untuk berwirausaha di Indonesia (Pertiwi, 2018). Kepemilikan tanah dengan status hak milik pada WNA yang ada saat ini biasanya dilakukan dengan membuatkan perjanjian nominee (perjanjian pinjam nama), dimana warga negara asing meminjam nama dari warga negara Indonesia untuk melakukan jual beli tanah di Indonesia.

Berhubung perjanjian nominee adalah perjanjian yang tidak sah karena telah melanggar ketentuan peraturan perundangundangan, khususnya dalam hal ini adalah ketentuan Pasal 21 ayat (1) dan ketentuan Pasal 26 ayat (2) UUPA, maka akibat hukum perjanjian nominee adalah perjanjian yang batal demi hukum, karena perjanjian nominee dibuat secara tidak sah, maka tidak mempunyai kekuatan hukum mengikat (Utari, 2017). Maka dengan adanya pelanggaran atas Pasal 21 ayat (1) juncto Pasal 26 ayat (2) UUPA, maka seharusnya adalah tanah tersebut dikembalikan ke negara. Hal 


\section{Akibat hukum terhadap jual beli tanah yang telah didahului perjanjian nominee dengan warga negara asing Norentia Ekumning Sari, Suhariningsih, Abdul Madjid}

ini terkait dengan asas nasionalitas yang dimiliki dalam UUPA. Esensi dari peradilan perdata adalah menilai siapa yang berhak dan siapa yang tidak berhak atas sebidang tanah terperkara, bukan menilaikeabsahan administratif penerbitan sertifikat dimaksud (Permata, 2018). Maka terkait gugatan atas penguasaan tanah melalui perjanjian nominee adalah ke Peradilan Umum.

Adapun penguasaan tanah hak milik di Indonesia terdiri dari 2 (dua) jenis penguasaan yakni dengan penguasaan secara fisik yakni menguasai secara nyata namun nama penguasa tanah tidak terdaftar dalam sertifikat tanah; dan Penguasaan secara juridis yakni tanah dikuasai secara hukum (yang berlaku di Indonesia), artinya nama pemegang dari hak atas tanah terdaftar atau tercatat dalam sertifikat tanah.

Aalasan yang paling penting dibuatnya perjanjian nominee adalah perjanjian tersebut dapat melindungi pembelian tanah oleh warga negara asing atas nama nominee, di mana warga negara asing tersebut tidak berhak untuk menguasainya (Hasibuan, 2016). Maka jika dilihat dari segi investasi, tentu saja perjanjian nominee bisa dapat memberikan lebih banyak keuntungan, tapi dengan ketentuan bahwa asas nasionalitas dalam UUPA tetap tercapai. Banyaknya keinginan masyarakat baik WNI maupun WNA untuk menguasai tanah di Indonesia secara fisik maupun juridis, banyaknya upaya tersebut membuat perjanjian tersebut dengan memberikan kuasa, dimana Warga negara indonesia memberikan kewenanggan seutuhnya bagi penerima kuasa yaitu WNA untuk melakukan segala perbuatan yang berkaitan dengan hak atas tanah, perjanjian itu pastinya dibuat oleh notaris dengan penguasaan tanah dengan hak milik oleh warga negara asing secara tidak langsung dan dapat dikatakan bahwa hal tersebut telah terjadi penyelundupan hukum.

Perjanjian nominee mengakibatkan ketidakpastian hukum, karena mengakibatkan adanya kepemilikan tanah secara de jure (legal owner) dan juga secara de facto (benefarctor). Putusan PN DPS 82/2013 akhirnya melihat perjanjian nominee yang dibuat oleh WNA dan WNI selain sebagai penyelundupan hukum. Akan tetapi putusan yang sama juga menyatakan bahwa WNA telah melakukan investasi di Indonesia, untuk hal tersebut maka haknya juga harus dilindungi. Ketidakpastian terhadap hak atas tanah kemudian mengakibatkan akan adanya pihak yang dirugikan.

\section{Metode}

Penelitian dalam artikel ini merupakan penelitian yuridis normatif yang merupakan penelitian yang mengkaji dan menganalisis aturan hukum yang bersifat formal yakni undang-undang. Pendekatan yang digunakan dalam analisa penelitian ini adalah pendekatan perundang-undangan (Statute Aprroach) dan pendekatan kasus (Case Approach). Pendekatan ini dilakukan dengan mengkaji semua undang-undang dan regulasi yang bersangkut paut dengan isu hukum yang penulis hadapi dalam penulisan tesis ini dan kasus berupa putusan pengadilan terkait perjanjian nominee dan jual beli berkaitan dengan perjanjian nominee. pendekatan ini akan dikaji kesesuaian undang-undang satu dengan undang-undang lain guna mendapatkan argumentasi yang sesuai. Bahan hukum dalam artikel ini menggunakan bahan hukum primer dan sekunder. Bahan hukum primer adalah bahan hukum yang memiliki sifat otoritas yakni bersifat kewenangan. Bahan hukum primer yang dimasukkan dalam penelitian ini berupa perundangudangan, catatan-catatan resmi atau risalah dalam pembuatan perundang-undangan dan putusanputusan hakim. Bahan hukum sekunder berupa penjelasan yang relevan digunakan sebagai panduan berpikir dalam menyunsun sebuah argumentasi terkait dengan Unifikasi hukum. Tehnik pengumpulan bahan hukum dengan studi kepustakaan dan Case Research. 


\section{Pembahasan}

\section{Akibat Hukum Terhadap Jual Beli Tanah yang Didahului Perjanjian Nominee Dengan Warga Negara Asing.}

Golongan masyarakat di Indonesia dikenal 2 kategori, yakni Warga Negara Indonesia (WNI) dan Warga Negara Asing (WNA) (Moechtar, 2020). Terkait dengan jual beli tanah yang dilakukan dengan menggunakan perjanjian neminee antara WNI dengan WNA, asas terang dan tunai dalam jual beli tanah mengakibatkan jual beli harus dilakukan di hadapan pejabat umum yang berwenang, yakni Pejabat Pembuat Akta Tanah (PPAT). Pembayarannya pun dilakukan pada saat bersamaan yakni pada waktu penanda tanganan Akta Jual Beli. Dengan adanya asas terang dan tunai, meskipun pada kondisi yang sebenarnya uang belum diserahkan sepenuhnya pada penjual, tapi dianggap proses jual beli telah selesai.

Perjanjian nominee bukan untuk WNI dan WNA saja tetapi antara WNI dengan WNI juga yang tujuannya adalah untuk menghindari pajak dan untuk memperbanyak kekayaan. Persoalan yang sering muncul diawali dengan wanprestasinya salah satu pihak mengakibatkan kedua belah pihak bersengketa (Dirawan, 2020). Pada studi kasus PN DPS 82/2013, Penggugat merupakan seorang WNA yang mengadakan perjanjian nominee dengan Tergugat I yang merupakan seorang Warga Negara Indonesia. Seiring dengan berjalannya waktu, Penggugat melalui Tergugat I mencari calon pembeli untuk tanah yang menjadi objek sengketa. Tergugat I kemudian menjual kepada Tergugat II tanpa pemberitahuan terlebih dahulu kepada Penggugat. Inilah yang menjadi dasar permasalahan dalam Putusan PN DPS 82/2013 ini.

Dengan adanya Pasal 1320 BW yang mengatur tentang perjanjian dan adanya juga UUPA sebagai lex specialis dalam hukum tanah, maka ada beberapa hal yang perlu diteliti lebih lanjut. Hal ini dikarenakan para pihak yang terlibat dalam perjanjian nominee biasanya berlindung pada BW, yakni pada pasal-pasal seperti 1320 BW, dan 1338 BW. Tetapi perlu diingat bahwa pasal 1320 BW dan 1338 BW terkait perjanjian nominee akan bertentangan jika dihadapkan dengan UUPA. Pada pasal 1320 BW terkait subjek dan objek dari suatu perjanjian jual beli, perjanjian nominee sendiri telah melanggar objek perjanjian jual beli yakni sebab yang halal. Hal ini dikarenakan perjanjian nominee memperjanjikan sesuatu yang telah dilarang dalam UUPA. Adalah menjadi sebuah hal yang menarik untuk dianalisis karena perjanjian nominee merupakan sebuah perjanjian innominaat atau perjanjian tidak bernama yang juga mempunyai kedudukan hukum dalam BW. Dalam penelitian sebelumnya yang dilakukan oleh Saputri, bahwa perjanjian nominee tidak memenuhi kausa yang halal dan batal demi hokum (Saputri, 2015).

Dengan adanya UUPA, maka peralihan hak atas tanah didasarkan pada PP 24/1997. Dalam Pasal 37 ayat (1) PP 24/1997 disebutkan bahwa, "Pemindahan hak atas tanah dan hak milik atas satuan rumah susun melalui jual beli, tukar menukar, hibah, pemasukan dalam perusahaan dan perbuatan hukum pemindahan hak lainnya, kecuali pemindahan hak melalui lelang hanya dapat didaftarkan jika dibuktikan dengan akta yang dibuat oleh PPAT yang berwenang menurut ketentuan perundang-undangan."

Para pihak seringkali melakukan perjanjian nominee dengan berlindung pada asas kebebasan berkontrak. Akan tetapi asas kebebasan berkontrak dalam BW tidak dapat berdiri sendiri. Dalam Pasal 1320 BW terdapat syarat-syarat sahnya suatu perjanjian, salah satunya adalah sebab yang halal. Jika hanya berdasar BW, maka perjanjian nominee yang dilakukan WNA dengan WNI adalah sah. Tetapi dengan adanya UUPA, yang khusus mengatur tentang tanah maka asas lex specialis legi lex generali berlaku. Maka dengan juga melihat teori hukum dari Gustav Rabruch, serta dikaitkan dengan Pasal 8 UU 12/2011 maka dapat dilihat bahwa BW dan 
UUPA merupakan ketentuan yang sederajat, yakni undang-undang. Dengan adanya UUPA yang mengatur tentang hukum agraria, khususnya tanah maka UUPA berlaku sebagai undang-undang yang bersifat khusus. Maka ketentuan terkait asas Nasionalitas dalam Pasal 21 dan Pasal 26 UUPA dapat mengenyampingkan asas kebebasan berkontrak dalam BW dan terkait sahnya suatu perjanjian.

Dengan menganalisis pada Putusan PN DPS 82/2013 maka dapat dilihat bahwa titik focus pertimbangan hakim (ratio decidendi) bukan saja pada perjanjian nominee yang dibuat dengan WNA, tetapi juga pada perjanjian jual beli antar WNI. Jika hanya berdasar pada perjanjian nominee maka hasil dari perjanjian nominee tersebut sudah jelas, yakni batal demi hukum. Hal ini sesuai dengan Pasal 21 UUPA dan juga pasal 26 UUPA. Akan tetapi, dengan adanya ketidakpastian hukum terkait hak atas tanah yang terjadi akibat adanya perjanjian nominee, mengakibatkan kepemilikan tanah objek sengketa terbagi menjadi 2 (dua), yakni kepemilikan tanah secara de jure (legal owner) yakni Tergugat I dengan bukti kepemilikan Sertifikat Hak Milik (SHM), dan Kepemilikan tanah secara de facto (benefactor) yakni Penggugat dengan bukti Surat Pernyataan dari Tergugat I terkait transaksi dan pembayaran yang dilakukan untuk memperoleh objek sengketa.

Anthony Aust menulis, "Recognition de jure means that the entity fully satisfies the applicable legal criteria; recognition de facto is only of the current position of the entity, and is therefore usually provisional."

Yang dapat diartikan bahwa, "Pengakuan secara de jure berarti bahwa entitas tersebut sepenuhnya memenuhi kriteria hukum yang berlaku; Pengakuan de facto hanya untuk posisi entitas saat ini, dan oleh karena itu biasanya bersifat sementara." Maka dengan interpretasi hukum, dapat dilihat bahwa perjanjian nominee yang dibuat di Indonesia terhadap tanah memiliki kedua unsur ini. Tidak adanya peraturan perundang-undangan yang khusus mengatur terhadap perjanjian nominee dengan hak atas tanah di Indonesia tidak berarti hakim tidak dapat menemukan hukum. Menurut Wiryanatha "Meskipun dalam sistem hukum Indonesia fungsi dan peran hakim di Pengadilan hanya sebagai 'corong undang-undang' (la bouche de la loi), akan tetapi karena sifat undang-undang yang sangat konservatif dan tanggung jawab penegakan kebenaran dan keadilan berada di pundak hakim, maka hakim dituntut untuk dapat menciptakan hukum melalui berbagai penafsiran hukum (wiryanatha, 2019)." Maka dengan demikian, undang-undang dan juga hukum merupakan produk dari manusia yang tentunya tidaklah sempurna. Maka dalam hal ini pula putusan hakim haruslah dianggap benar, sesuai dengan asas "res judicata pro veritate habetur" yakni putusan hakim harus dianggap benar.

Terkait penemuan hukum dalam pertimbangan hakim, menurut Junaidi bahwa, "Hakim wajib untuk memeriksa dan mengadili setiap perkara yang diajukan oleh masyarakat." Maka hal ini sesuai dengan ketentuan sebagaimana dalam Pasal 10 UU Nomor 48 Tahun 2009 tentang Kekuasaan Kehakiman. Di dalam UU Kekuasaan Kehakiman juga terdapat ketentuan dalam Pasal 5 bahwa hakim harus dapat memahami, menggali dan juga mengikuti nilai-nilai hukum yang ada di masyarakat apabila terjadi suatu perkara yang tidak ada hukumnya. Hal yang sama juga ditegaskan dalam penelitian Ardiansyah, "Bahkan sering kali hakim harus menemukan sendiri hukum itu (rechtsvinding), dan/ atau menciptakan (rechtsschepping), untuk melengkapi hukum yang sudah ada, dalam memutus suatu perkara. Hakim atas inisiatifsendiri harus menemukan hukum." Maka dapat dilihat bahwa terkait perjanjian nominee dalam kaitannya dengan hak atas tanah di Indonesia maka hakim akan melakukan penemuan hukum. Kemudian yang menarik dari Putusan PN DPS 82/ 2013 adalah pertimbangan hakim terkait tindakan 
jual beli antara Tergugat I dengan Tergugat II sebagai sebuah Perbuatan Melawan Hukum (PMH).

Tindakan Tergugat I menjual hak atas tanah ke Tergugat II (dari ke WNI ke WNI) dengan melihat pertimbangan hakim maka telah memenuhi unsur perbuatan melawan hukum, yakni bahwa: (1). Tergugat I sebelumnya telah mempunyai hutang, dan ingin menutup hutang yang lama dengan cara membuat hutang yang baru; (2). Saksi ahli untuk menakar harga tanah menjelaskan bahwa objek sengketa tersebut dapat dijual seharga Rp. 8.500.000.000,- (delapan miliar lima ratus juta Rupiah) sampai dengan Rp. 9.000.000.000,(Sembilan miliar Rupiah). Tergugat I menjual hak atas tanah kepada Tergugat II senilai $\mathrm{Rp}$. 6.000.000.000,- (enam miliar Rupiah lima ratus juta). Dengan kata lain, objek sengketa dijual di bawah harga pasar; (3). Ada bukti Surat Kuasa antara Tergugat I dengan Penggugat untuk mengalihkan hak atas objek sengketa; (4). Ada bukti Surat Pernyataan dari Tergugat I kepada Penggugat bahwa semua urusan keuangan terkait objek sengketa (pembelian tanah, administrasi dan pembangunan villa) diserahkan kepada penggugat; (5). Akta Jual Beli beli terancam batal demi hukum karena saksi yang dihadirkan Tergugat I tidak dapa menjelaskan kepastian waktu pada saat tanda tangan AJB.

Menurut penulis, adanya tindakan Penggugat yang merupakan WNA untuk menjual tanah dan bangunan tersebut sebelum adanya gugatan merupakan salah satu yang menjadi pertimbangan hakim dalam memutus perkara ini. Ditambah lagi, Tergugat I menjual tanah tersebut dibawah harga pasar. Maka perbuatan melawan hukum yang dilakukan oleh Tergugat I dengan Tergugat II atas jual beli hak atas objek sengketa harus dapat dipertanggungjawabkan oleh para Tergugat. Tentu saja Penggugat juga tidak luput dari tanggung jawab atas perjanjian nominee yang dibuatnya terlebih dahulu dengan Tergugat I. Dalam perkara ini, bukan saja keadilan dan kepastian hukum yang dikemukakan oleh Gustav Rabruch harus terpenuhi, tetapi juga tanggung jawab para pihak atas setiap perbuatan di dalam hukum. Hal ini sesuai dengan
Pasal 27 ayat (1) UUD 1945, “Segala warga negara bersamaan kedudukannya di dalam hukum dan pemerintahan dan wajib menjunjung hukum dengan tidak ada kecualinya." Dengan kata lain, tidak dapat dibenarkan suatu perbuatan hukum dari seorang WNI yang melanggar hak WNA.

Menurut Azhari, terkait pelanggaran akibat PMH adalah berupa: "Sanksi keperdataan yaitu sanksi yang dijatuhkan apabila terhadap kesalahan yang terjadi, baik karena Wanprestasi ataupun Perbuatan Melanggar Hukum (onrechtmatigedaad) (Anzhari, 2018)". Pada PMH antara Tergugat I dan Tergugat II, perjanjian jual beli yang telah dilakukan telah memenuhi prinsip "tanggung jawab berdasarkan unsur kesalahan”. Prinsip ini berlaku dalam hukum pidana dan juga hukum perdata. Dalam prinsip ini mensyaratkan tanggung jawab seseorang secara umum hanya jika ada unsur keasalahan yang telah dilakukan. Dalam hukum perdata diatur dalam 1365, 1366, dan 1377 BW. Penulis menganalis bahwa definisi kesalahan sebagaiman dimaksud dengan prinsip ini adalah telah sesuai dengan Pasal 1365 BW yakni suatu kesengajaan yang mengakibatkan adanya kerugian pada pihak lain.

Dalam pasal 1365 terkait PMH ini harus memenuh beberapa unsur sehingga dapat dikatakan perbuatan jual beli yang dilakukan antar Tergugat I dan Tergugat II merupakan sebuah perbuatan yang melawan hukum.

Pertama, adalah adanya suatu perbuatan, yakni pada jual beli antara Tergugat I dengan Tergugat II. Pelaku menngawai suatu perbuatan yang merupakan perbuatan melawan hukum. Adapun yang dimaksud dengan perbuatan adalah sesuatu yang dilakukan ataupun tidak dilakukan oleh seseorang. Karena itu, terhadap perbuatan melawan hukum, tidak ada unsur "persetujuanatau kata sepakat" dan tidak ada unsur "causa yang diperbolehkan" sebagaimana yang terdapat dalam kontrak.

Kedua, perbuatan tersebut melawan hukum. Perbuatan melawan hukum antara Tergugat I dengan Tergugat II melalui jual beli objek sengketa 


\section{Akibat hukum terhadap jual beli tanah yang telah didahului perjanjian nominee dengan warga negara asing Norentia Ekumning Sari, Suhariningsih, Abdul Madjid}

tanpa memberitahukan terlebih dahulu kepada Penggugat merupakan sebuah pelanggaran terhadap hak Penggugat. Terkait hal ini, perkara Lindenbaum-Cohen di Hoge Raad (Mahkamah Agung Belanda) tahun 1919 menjadi terkenal dan merupakan salah satu cara dalam penemuan hukum dalam hukum perdata. Secara singkat, LindenbaumCohen adalah perkara dimana pihak penerbit Cohen berusaha membujuk pegawai Lidenbaum agar membocorkan daftar pelanggan Lindenbaum agar pihak Cohen dapat memperoleh keuntungan lebih besar. Tindakan ini diketahui pihak Lindenbaum dan menggugat dengan Pasal 1401 (1365 KUH Perdata Indonesia) terkait perbuatan melawan hukum (onrechtmatige daad). Karena tidak jelasnya makna Pasal tersebut terhadap perkara, maka hakim melakukan penemuan hukum dengan memperjelas atau memperluas makna dari sebuah "perbuatan melawan hukum".

Ketiga, terdapat kesalahan yang berasal dari pihak pelaku. Agar tindakan jual beli antara Tergugat I dan Tergugat II dapat dikenakan Pasal 1365 BW tentang PMH, maka perbuatan tersebut harus terdapat unsur-unsur kesalahan (schuldelement) sebagaimana dimaksud oleh undang-undang dan juga yurisprudensi. Dalam Pasal 1365 BW tidak menganut prinsip tanggung jawab tanpa kesalahan (strict liability). Jika suatu hal tertentu dikategorikan sebuah strict liability, maka kategori strict liability sebagaimana dimaksud adalah karena berasal dari peraturan atau undang-undang yang lain. Dalam Pasal 1365 BW lebih menitikberatkan pada unsur "kesalahan" (schuld), sehingga perlu didefinisikan secara khusus terkait sejauh manakah cakupan dari "kesalahan" sebagaimana dimaksud. Di dalam unsur kesalahan yang dapat dimintai pertanggungjawaban hukum adalah jika memenuhi unsur-unsurnya yakni: sebuah kesengajaan; merupakan sebuah kelalaian; dan tidak terdapat suatu alasan pembenar atau peamaaf. Tindakan Tergugat I dalam menjual objek sengketa dengan harga yang tidak sesuai dengan harga minimum yang berlaku pada saat itu menurut hakim telah memenuhi unsur ini.
Keempat, adanya kerugian bagi korban. Penggugat dalam kasus ini meskipun seorang WNA, tapi dalam pokok gugatannya menyatakan bahwa telah mengalami kerugian materiil maupun immateriil. Di dalam PMH Pasal 1365 juga diperlukan syarat kerugian terhadap korban (schade). Kerugian yang muncul pada PMH Pasal 1365 BW dapat berupa kerugian materiil dan kerugian immaterril.

Kelima, adanya hubungan sebab akibat antara perbuatan dengan kerugian. Dalam gugatannya, Penggugat mendalilkan bahwa akibat penjualan objek sengketa oleh Tergugat I yang dilakukan tanpa sepengathuannya mengakibat dia mengalami kerugian. Terdapat sebuah hubungan sebab akibat dari perbuatan yang kemudian mengakibatkan kerugian pada seseorang. Pada unsur sebab akibat perbuatan dengan kerugian ini terdapat 2 macam teori yang dapat dipakai yakni; teori hubungan factual (causation fact) dan teori penyebab sementara. Kedua teori ini menyatakan bahwa dalam sebab akibat antara perbuatan dengan kerugian diperlukan fakta atau kenyataan hukum tentang apa yang terjadi.

Maka apakah dapat dapat dikaitkan PMH atas perjanjian jual beli Tergugat I dengan Tergugat II, yakni apakah perlu dipersyaratkan unsur "kesalahan" disamping unsur "melawan hukum" dalam suatu perbuatan melawan hukum, apakah tidak cukup dengan unsur "melawan hukum "saja. Dengan melihat unsur-unsur terkait perbuatan melawan hukum di atas maka dapat disimpulkan bahwa apa yang telah dilakukan oleh Tergugat I dan Tergugat II terkait perjanjian jual beli yang mereka lakukan telah memenuhi syarat sebuah perbuatan melawan hukum.

\section{Simpulan}

Perjanjian nominee merupakan sebuah perjanjian innominaat yang ada di Indonesia. Terkait perjanjian nominee itu sendiri, pada dasarnya telah memenuhi syarat sahnya sebuah perjanjian, akan tetapi dengan adanya penyelundupan hukum berupa adanya WNA sebagai pihak dalam 
perjanjian nominee mengakibatkan perjanjian ini rentan terhadap gugatan. Hal ini dikarenakan WNA sebagai pihak dalam perjanjian nominee merupakan suatu hal yang telah dilarang dalam UUPA. UUPA sebagai lex specialis menempatkan posisinya dengan mengesampingkan $\mathrm{BW}$, sehingga dengan sendirinya perjanjian nominee tersebut batal demi hukum.

Putusan hakim terkait jual beli antar Tergugat I dan Tergugat II yang dilakukan tanpa sepengatahuan oleh Penggugat juga merupakan sebuah perbuatan melawan hukum. Hal ini dikarenakan tindakan dari para Tergugat ini dianggap hakim telah melanggar hak dari seorang WNA yang telah berinvestasi berupa modal uang di Indonesia. Akan tetapi, investasi dari Penggugat ini juga dibarengi dengan perjanjian nominee yang juga memenuhi syarat untuk batal demi hukum. Jika ada WNA yang ingin berinvestasi di Indonesia secara langsung, sebaiknya menggunakan cara penanaman modal asing melalui perseroan terbatas, atau melalui perjanjian sewa menyewa.

\section{Daftar pustaka}

Ardiansyah. 2020. Pembaruan Hukum oleh Mahkamah Agung Dalam Mengisi Kekosongan Hukum Acara Perdata di Indonesia. Jurnal Ilmiah Kebijakan Hukum 14(2): 370.

Aust, Anthony. 2005. Handbook of International Law. Cambridge: University Press.

Azhari, M. Edwin. 2018. Tanggung Jawab Notaris Dalam Pembuatan Akta Perjanjian Nominee dalam Kaitannya Dengan Kepemilikan Tanah oleh Warga Negara Asing di Lombok. Jurnal Akta, 5 (1): 46.

Dirawan, Dedy Arya. 2020. Penyelesaian Konflik Akibat Perjanjian Nominee Dalam Perspektif ADR. Jurnal Acta Comitas, 5 (1): 41.

Hasibuan, Nella. 2016. Pembuatan Perjanjian Nominee Sesuai Undang-Undang Pokok Agraria. Jurnal Notariil 1 (1): 41.

Junaidi, dan Merta, M. Martindo. 2020. Asas Hakim Pasif Dalam Reglement Op de Rechtsvordering ( $R V)$ dan
Prinsip Hakim Aktif Dalam Herzienne Indonesisch Reglement (HIR) Dalam Penyelesaian Perkara Perdata di Pengadilan. Jurnal Ilmiah Ilmu Hukum QISTIE 13(1): 71.

Kitab Undang Undang Hukum Perdata.

Lailawati, F.D. (2020). Penghapusan diskriminasi, ras, dan etnis pembuatan surat keterangan waris yang didasarkan pada penggolongan penduduk. Jurnal Cakrawala Hukum. 11(1), 1220.doi:10.26905/ idjch.v11i1.4051.

Moechtar, O, Valentino, B \& Wahyono, D.C., (2020). Kajian komparatif lembaga penolakan waris dalam perspektif hukum. Jurnal Cakrawala Hukum, 11(3). 291-301. doi:10.26905/idjch.v11i3.42.

Permata, Shirly Claudia. 2018. Implementasi Putusan Hakim Terhadap Pembatalan Sertifikat Hak Milik Atas Tanah. Jurnal IUS 6(3); 473.

Pertiwi, Endah. 2018. Tanggung Jawab Notaris Akibat Pembuatan Akta Nominee yang Mengandung Perbuatan Melawan Hukum Oleh Para Pihak. Jurnal IUS 6 (2): 246.

Putra, A. A. Ngurah Agung Satriya Prabawa. 2017. Keabsahan Perjanjian Nominee oleh Orang Asing Dalam Kepemilikan Tanah di Bali. Jurnal Ilmu Hukum Kertha Semaya 5 (1): 3.

Saputri, Andina Damayanti. 2015. Perjanjian Nominee Dalam Kepemilikan Tanah Bagi Warga Negara Asing yang Berkedudukan di Indonesia. Jurnal Repertorium, 2 (2): 103.

Undang Undang Dasar Negara Republik Indonesia Tahun 1945.

Undang-Undang Republik Indonesia Nomor 12 Tahun 2011 tentang Pembentukan Peraturan PerundangUndangan.

Undang-Undang Republik Indonesia Nîmîr 25 Tahun 2007 tentang Penanaman Modal.

Undang-Undang Republik Indonesia Nîmîr 5 Tahun 1960 tentang Peraturan Dasar Pokok-Pokok Agraria.

Wiryanatha, I Made Ariwangsa. 2019. Akibat Putusan Hakim yang Melanggar Hukum dalam Pemilikan Tanah oleh Orang Asing. Jurnal IUS 7(3): 420.

Đutusan Pengadilan Negeri Denpasar No. 82/PDT.G/ 2013/PN.DPS. 